\title{
Effect of Islamic-based repentance therapy on the prevention of Post-traumatic Stress Disorder (PTSD)
}

\author{
Qurotul Uyun, ${ }^{1 *}$ Nahdhata Jaufalaily, ${ }^{2}$ Evelin Witruk, ${ }^{3}$ Irwan Nuryana Kurniawan ${ }^{1}$ \\ ${ }^{1}$ Faculty of Psychology and Socio-Cultual Sciences, Universitas Islam Indonesia, Yogyakarta - Indonesia; \\ ${ }^{2}$ Faculty of Psychology, Universitas Gadjah Mada, Yogyakarta - Indonesia; ${ }^{3}$ Institute of Psychology, \\ University of Leipzig, Leipzig - Germany
}

\begin{abstract}
This research is based on the tragedy of a road traffic accident that led to a student's death. Her classmates felt lost and experienced symptoms of Post-traumatic Stress Disorder (PTSD). The purpose of the study is to examine the effectiveness of repentance and istighfar therapy to prevent PTSD. The research was based on a quasi-experimental design that consisted of six sessions in three meetings and homework for four weeks. The study participants were 14 students who experienced PTSD symptoms. They completed a scale before the intervention (pre-test), after completion of the intervention (post-test), and three weeks after the post-test. The paired sample test analysis results show that there were significant differences in the trauma scores pre-therapy and post-therapy. The effect size estimation results show that the effect of repentance and istighfar therapy was in the large effect size category; that is, $80.9 \%$ of the trauma variations could be explained (caused) by repentance therapy and istighfar. The research implies that such therapy can be predicted to be effective in reducing psychological disorders, as long as they are willing to be seriously involved in each stage of the therapy process that has been determined.
\end{abstract}

Keywords: repentance and istighfar therapy; PTSD; traffic accident

\begin{abstract}
Abstrak: Penelitian ini dilatarbelakangi oleh kasus kecelakaan lalu lintas yang berakibat seorang mahasiswi meninggal, kemudian menyebabkan teman-teman kelasnya merasakan kehilangan dan mengalami gejala-gejala Post-traumatic Stress Disorder (PTSD). Tujuan penelitian ini untuk menguji efektivitas terapi taubat dan istighfar untuk mencegah terjadinya PTSD pada mereka. Metode yang digunakan dalam penelitian ini menggunakan desain quasi experimental yang terdiri 6 sesi dalam 3 pertemuan, dan tugas rumah yang dilakukan selama 4 minggu. Partisipan dalam penelitian ini adalah 14 mahasiswa yang mengalami gejala-gejala PTSD. Partisipan mengisi skala sebelum intervensi (pra-tes), setelah selesai intervensi (pasca-tes), dan 3 minggu setelah pasca-tes. Hasil analisis paired sample test menunjukkan terdapat perbedaan yang signifikan antara trauma praterapi dan trauma pasca-terapi. Hasil estimasi effect size menunjukkan pengaruh terapi taubat dan istighfar termasuk dalam kategori large effect size, yakni 80,9\% perubahan variasi trauma dapat dijelaskan (disebabkan) oleh terapi taubat dan istighfar. Implikasi penelitian ini adalah terapi taubat dan istighfar dapat diprediksikan efektif dalam menurunkan gangguan psikologis, sejauh mereka bersedia terlibat secara serius untuk mengikuti setiap tahap-tahap proses terapi yang sudah ditentukan.
\end{abstract}

Kata Kunci: terapi taubat dan istighfar; PTSD; kecelakaan lalulintas

\footnotetext{
*Corresponding Author: Qurotul Uyun (qurotuluyun@yahoo.com), Faculty of Psychology and Socio-Cultural Sciences, Universitas Islam Indonesia, Jl. Kaliurang Km 14,5 Sleman, Yogyakarta 55584 - Indonesia.
} 


\section{Introduction}

Death and loss are natural parts of the life cycle. However, they may be more difficult to cope with when they happen in unexpected and traumatic ways, such as the loss of a friend through an accident. The World Health Organization (WHO) World Mental Health Surveys of 24 countries $(n=68,894)$ report that the most common traumatic experiences are the unexpected death of a loved one (31.4\%) and direct exposure (witnessing or discovering) to death or serious injury (23.7\%) (Kessler et al., 2017). The sudden death of a loved one has been shown to predict the onset of multiple mental disorders, including Post-traumatic Stress Disorder (PTSD) across childhood and through to adulthood (Keyes et al., 2014). PTSD is a psychological disorder that occurs in people who have experienced extremely threatening or upsetting events (Bisson et al., 2015). If left untreated, it can lead to a significant reduction in the quality of life and functional capability, emotional impairment, predisposition to other pathologies, and a greater likelihood of suicide attempts (Davidson, 2000).

People react to traumatic events differently, ranging from relatively mild to severe and debilitating effects (Wainrib, 2006). Several common traumatic symptoms include anxiety, terror, shock, upset, emotional numbness and personal or social isolation. Traumatic events are often accompanied by nightmares and other symptoms such as depression, irritability, sleep disorders, and anxiety. Despite experiencing a traumatic event, not everyone who is traumatized develops either prolonged (chronic) or short-term (acute) PTSD, and not all PTSD sufferers have experienced a devastating event. According to the Diagnostic and Statistical Manual of Mental Disorders (American Psychiatric Association,
2013), symptoms of PTSD usually start early, within 3 months of the traumatic incident, but in some cases they are present years later. To be considered as PTSD, symptoms must last for more than one month and be severe enough to interfere with relationships or work. The course of the disorder varies. Some people recover within 6 months, while others have symptoms that last longer. In some, the condition becomes chronic. According to the DSM-5, PTSD diagnosis should be made at least 1 month after the incident has taken place. In this study, at the time of joining the intervention session the participants were still within two weeks of the accident. Even though they could not be diagnosed for PTSD, they had experienced a traumatic event that was very stressful and uncomfortable, so it can be assumed that they were experiencing PTSD symptoms that needed urgent help to avoid them becoming a prolonged psychological disorder. If PTSD symptoms are not immediately intervened, this will cause more severe psychological problems.

DSM-5 further notes that the diagnosis of PTSD can be made when an adult has experienced one or more of the following symptoms for within one month: re-experiencing symptoms, avoidance symptoms, arousal and reactivity symptoms, or cognition and mood symptoms. Re-experiencing symptoms include flashbacks, reliving of the trauma repeatedly, and physical symptoms. These may be linked to the thoughts and feelings of sufferers themselves. Words, objects or situations that remind them of the traumatic event are likely to retrigger the symptoms. Avoidance symptoms include distancing oneself from places, events or objects that trigger a reminder of the traumatic experience, and avoiding thoughts or feelings associated with the traumatic event. Reactivity symptoms include being easily startled, experi- 
encing tense feelings, sleeping difficulties, nightmares, and irritability, while arousal symptoms are usually constant, rather than being triggered by a reminder of the traumatic event. These symptoms can cause people to feel stressed and angry and struggle to perform daily tasks.

Certain factors play a role in determining whether a person is at risk of developing PTSD (Sareen, 2014). Some of these include having been through life-threatening events and trauma; having been injured; seeing other people hurt or die; childhood trauma; lack of social support; the sudden death of a loved one; having a history of mental illness; substance abuse; and other life stress (Creamer et al., 2001; Keyes et al., 2014; Perrin et al., 2014; Sareen, 2014). On the other hand, resilience factors can help reduce the risk of psychological disorders (Sareen, 2014). After a traumatic event, people who look for support networks are at a lower risk of developing PTSD (Charuvastra \& Cloitre, 2008; Gros et al., 2016). Furthermore, people are less likely to develop it when they have positive coping strategies or are able to act and respond effectively to difficult situations (Read et al., 2014). Researchers have studied the importance of these risk factors and resilience, including genetic and neurobiological factors (Skelton et al., 2012). If more research were conducted in these areas, it would be possible to predict PTSD tendencies and prevent the disorder.

Several treatments have been previously used to alleviate PTSD symptoms. For example, cognitive behavioral therapy (CBT) has been widely utilized in its treatment. The collection of articles reviewed by Kar (2011) describe the effects of PTSD following different types of trauma (i.e., war trauma, sexual violence, sexual abuse, terrorist attacks, road traffic accidents, natural disasters, man-made traumas, and trauma in disaster workers and refugees). It also addresses the possible prevention of PTSD, the techniques used in CBT, and the underlying neuropsychological mechanisms of CBT treatments for PTSD. Several cognitive-behavioral programs have been demonstrated to be effective for implementing children, adolescents, and preschoolers with PTSD. CBT treatments for PTSD have been applied in various settings, including community centers, schools, primary care clinics, and hospitals at the secondary and tertiary care levels (depending on the state of the trauma).

Psychotherapists who are experts in PTSD have offered general principles for PTSD treatment, namely 1) building trust in the therapeutic relationship; 2) educating clients on how to cope with the trauma; 3) stress management training; 4) helping clients approach the trauma; and 5) integrating the traumatic event into the individual's experience (Scurfield, in Oltmanns \& Emery, 2003). Researchers have also shown that imagery rehearsal therapy (IRT), a type of cognitive-behavioral intervention, can lower nightmares' number and intensity (Casement \& Swanson, 2012). Nightmare disorder is a sleep disorder commonly associated with PTSD. In IRT, therapists guide clients to learn that nightmares result from habit, as is the case with trauma, and strengthen them psychologically in order to reduce them. They are instructed to write down the new versions of their nightmares once they wake up.

Sijbrandij, Olff, Reitsma, Carlier, De Vries, and Gerson (2007) conducted a randomized controlled trial on 143 patients with acute PTSD following various types of psychological trauma 
within 3 months of the traumatic incidents. Their CBT intervention program consisted of four weekly sessions, including education, relaxation exercises, imagery exposure, in vivo exposure, and cognitive restructuring. Their results show that brief early cognitive behavioral therapy reduced symptoms of PTSD, anxiety and depression in both groups over time. The intervention accelerated the improvement of acute PTSD symptoms, but it did not influence the long-term outcomes. In addition, Bisson et al. (2015) recommend exposure therapy, CBT and Eye Movement Desensitisation Reprocessing (EMDR) to treat trauma.

Empirical evidence has shown how mental health can be enhanced by integrating spirituality and religion into psychotherapeutic practices. Harris, Thoresen, McCullough, and Larson (1999) reviewed a number of religious and spiritual interventions currently available or widely applied in psychotherapy. They concluded that cognitive therapy with religious approaches, meditation, forgiveness interventions, and prayer provided empirical evidence of improved health. Pearce, Haynes, Rivera, and Koenig (2018) developed Spiritually Integrated Cognitive Processing Therapy (SICPT) as an intervention for PTSD. SICPT uses spiritual concepts and rituals of compassion, grace, spiritual guided imagery, repentance, confession, forgiveness, atonement, blessing, restitution, and making amends. It encourages patients to seek support from religious communities to strengthen their recovery and reintegration. Wainrib (2006) explains that trauma healing can be based on a spiritual paradigm and encourages clients' capacity for selfgrowth instead of despair.

Several recent studies have documented the effectiveness of psychological interventions that integrate Islamic teachings and rituals. For example, Khairiyah, Prabandari, and Uyun (2015) found that dhikr therapy could increase lower back pain sufferers' resilience levels. Another intervention study used the Islamic concept of patience, sabr, and salah prayer, with the findings showing that the intervention was effective in reducing psychopathological symptoms (Uyun \& Witruk, 2017). Correlational research has also revealed links between Islamic religiosity and several well-being variables, such as meaning in life and marital satisfaction in married couples (Gisela \& Kurniawan, 2014; Harits \& Kurniawan, 2016).

Repentance therapy based on the Islamic principles of tawba (repentance) and istighfar (seeking forgiveness) has also been developed (Uyun et al., 2019; Uyun \& Kurniawan, 2018). The results of these studies showed that this type of therapy was effective in improving mental health and subjective well-being among college students. The studies also explored the daily journals written by the participants. They reported feeling a wide range of changes, such as lower levels of anxiety, anger, and obsessive-compulsive disorder symptoms. Furthermore, the results demonstrated that this intervention had a positive effect on emotion regulation, positive thinking, happiness and faith in God.

Early Islamic scholars defined and explained the concept of tawba by referring to the Quran and Hadith. The word tawba can be traced to the Arabic verb tāba, which translates as "to return" or "to turn back." Al-Ghazali (2013) defined tawba as turning away from sin you have committed, preventing yourself from repeating it in the future, and correcting the mistakes that you have made due to not performing good deeds in the past. Tawba concerns the act of leaving God's 
prohibitions and following His commands (Philips, 1990). Repentance means that humans strive to purify themselves and to return to their original disposition in a sinless state (also known as fitra).

Islam asserts the importance of tawba. The command to repent can be found in chapter 24 of the Quran: "And turn to Allah in repentance, all of you, 0 believers, that you might succeed" (QS. alNūr [24]:31). Another chapter relates tawba to the concept of soul purification: "Indeed, Allah loves those who are constantly repentant and loves those who purify themselves" (QS. alBaqarah [2]:222). Narrated in the Hadith, the Prophet Muhammad said: "O people, seek repentance from Allah. Verily, I seek repentance from Him a hundred times a day" (al-Naishabūry, n.d., p. 35: 6523). Chapter 11 verse 61 commands Muslims to seek forgiveness and repent, and Allah promises mercy and grants the prayers of those who plead with Him:

"And to Thamud [We sent] their brother Salih. He said, "O my people, worship Allah; you have no deity other than Him. He has produced you from the earth and settled you in it, so ask forgiveness of Him and then repent to Him. Indeed, my Lord is near and responsive" (QS. Hūd [11]:61).

The pillars of tawba show the sincerity of the repentance. A person who truly repents shows remorse for the thoughts and bad deeds they have committed and are determined to put aside those wrongdoings. Al-Jauziyyah (2014) identified six characteristics of a repentant person: (1) maintaining relationships with pious people and avoiding those who have negative influences; (2) improving their behavior; (3) overcoming sin and accepting virtues with an open mind; (4) feeling constant fear of God's wrath and punishment; (5) detachment from worldly desires and the tendency towards divine values; and (6) being mindful of their thoughts and actions.

There are certain conditions which should be satisfied for one's repentance to be accepted. AlUtsaimin (2015) defined five such conditions of repentance. First, the performance of tawba should be solely intended to expect repentance and forgiveness from Allah instead of for other reasons (e.g., expecting praise from others). Second, one should feel remorse for having committed acts that are prohibited in Islam. Third, there should be a sincere intention to stop committing misdeeds, which is the most important requirement of tawba. Fourth, one should have the determination not to repeat the sin in the future. If a person intends to repeat it again once they have a chance, then their repentance will not be accepted. And fifth, tawba should be performed before it is too late. For example, repenting shortly before death would not be valid because it is done in a forced manner. Another condition for accepting repentance is asking forgiveness for misdeeds towards fellow humans.

If $\sin$ results from such a misdeed, then repentance is intended to improve one's relations with others. The cleanliness of the soul that results from repenting to Allah can lead people to interact positively with others. According to AdzDzakiey (2007), and based on the Al Quran and Hadith, mental health indicators are characterized by a good relationship with Allah, with oneself and other people, and with the universe. If there is disharmony in the relationship between people and themselves, Allah, other people or the universe, they will experience an imbalance that causes sin. This can lead to psychological disorders and mental health problems. The sins and mistakes humans have committed are course 
of anxiety. Sins typically stem from problems in maintaining good relationships with other people and with God. People who keep committing misdeeds may feel intrusive anxiety, which could increase the likelihood of developing mental disorders. Based on this perspective, Muslims should continually erase their sins through repentance, a process called 'soul purification' (also known as tazkiyah al-nafs). Tawba and istighfar are processes of seeking forgiveness from Allah and apologizing others for their mistakes. This involves a soul healing process which helps Muslims to build a sense of peace of mind. People may experience pathological guilt, anxiety or nightmares following a traumatic event. Therefore, we propose that repentancefocused interventions are needed to reduce these symptoms. From the Islamic perspective, the development of PTSD symptoms might stem from the lack of belief in Allah's will, as without this belief, a person may not be willing to accept situations that turn out contrary to their expectations. A lack of faith can be considered as a form of mistake or sin committed against God. Denial of God's will creates intense feelings of anxiety and guilt for the victim (for example, a deceased friend). In such situations, Muslims should strengthen their belief that any event or disaster in life happens by God's will. They need to understand the importance of repenting to Allah in order to release their feelings of pathological guilt (e.g., adopting the attitude that dwelling on mistakes will not change anything, while sending prayers might help the deceased person in the afterlife). Seeking God's forgiveness would lead them to a sense of gratitude and a calm state of mind, enabling them to recover from the traumatic event.
Traumatic symptoms include guilt, nightmares, avoidance and flashbacks, which require interventions that involve spiritual healing. In Islam, they are believed to be caused by a lack of faith in God's provision, which may trigger the development of psychological disorders. Repenting and reciting istighfar are means of remembering Allah. This method is encouraged for Muslims to overcome life's trials and difficulties and gives them a sense of belief that it is God who brings these challenges, so they should try to cope by returning their problems and negative feelings to God. This study re-implements tawba and istighfar therapy as a trauma healing tool to reduce the post-traumatic symptoms of college students who had lost a friend in a traffic accident. We hypothesize that this therapy will be effective and feasible in reducing the participants' levels of posttraumatic symptoms and preventing the development of PTSD.

\section{Method}

This research was conducted to evaluate tawba and istighfar intervention on 14 college students who experienced traumatic symptoms after losing a friend in a traffic accident. The friend was riding a motorcycle and was hit from the opposite direction by a teenager who was riding another motorcycle at high speed.

Post-traumatic stress disorder symptoms were measured using the PTSD checklist (PCL), which was developed to measure both the frequency and intensity of PTSD symptoms in a brief self-report format (Holliday et al., 2015). The PCL is a 17-item self-report questionnaire that assesses the severity of PTSD symptoms based on the Diagnostic and Statistical Manual of Mental Health Disorders, Fourth Edition (DSM-IV-TR). According to Lang et al. (2012), the PCL is a well- 
established self-reporting measure of PTSD symptoms with good validity and reliability (Cronbach's alpha: .886).

The study employed a quasi-experimental design (Field \& Hole, 2008). In such a design, researchers do not have complete control over the manipulation of independent variables. The following section is an overview of the design applied in this research.

The participants underwent tawba and istighfar intervention for trauma healing after the sudden death of a friend in a traffic accident. The intervention was conducted over six sessions, three meetings and four weeks of homework assignments. The participants completed a PCL before the intervention as a pre-treatment (baseline). A post-test was completed immediately after the intervention, and a follow up three weeks after the post-test. The homework assignments were given between the sessions. An outline of the sessions is provided in Table 1.

An evaluation of the effects of the intervention was made by examining the diaries written by the participants, who wrote down their daily experiences during the overall intervention process and discussed these in the

Table 1

Overview of the Tawba and Istighfar Intervention Program for PTSD

\begin{tabular}{|c|c|c|}
\hline Module & Theme & Objectives \\
\hline 1 & Introduction & $\begin{array}{l}\text { Engaged participants in the intervention. Presented the } \\
\text { program overview. }\end{array}$ \\
\hline 2 & Disclosure of symptoms & $\begin{array}{l}\text { Explored participants' negative emotions, cognitive } \\
\text { distortions and situations they were avoiding after the } \\
\text { accident. }\end{array}$ \\
\hline 3 & Awareness of symptoms & Provided participants with knowledge of PTSD. \\
\hline 4 & $\begin{array}{l}\text { Connecting the incident with } \\
\text { Allah }\end{array}$ & Guided the participants to find meaning in the incident. \\
\hline \multirow[t]{2}{*}{5} & $\begin{array}{l}\text { Understanding of tawba and } \\
\text { istighfar }\end{array}$ & $\begin{array}{l}\text { Taught the participants how to return their feelings and } \\
\text { thoughts to Allah through repenting and seeking } \\
\text { forgiveness. }\end{array}$ \\
\hline & & Described the pillars of tawba and istighfar. \\
\hline 6 & $\begin{array}{l}\text { Procedure to perform tawba and } \\
\text { istighfar }\end{array}$ & Explained how to perform tawba and istighfar. \\
\hline 7 & Homework assignment & $\begin{array}{l}\text { Asked participants to perform tawba and istighfar at } \\
\text { home for one week. }\end{array}$ \\
\hline \multicolumn{3}{|r|}{ ( } \\
\hline 8 & $\begin{array}{l}\text { Reflection session on tawba and } \\
\text { istighfar }\end{array}$ & $\begin{array}{l}\text { Discussed the experiences, events, thoughts and feelings } \\
\text { in the previous week. }\end{array}$ \\
\hline 9 & Homework assignment & $\begin{array}{l}\text { Asked participants to perform tawba and istighfar at } \\
\text { home for three weeks. }\end{array}$ \\
\hline \multicolumn{3}{|r|}{ (1) } \\
\hline 10 & $\begin{array}{l}\text { Reflection session on tawba and } \\
\text { istighfar }\end{array}$ & $\begin{array}{l}\text { Participants wrote down all their thoughts and feelings } \\
\text { about the previous three weeks. }\end{array}$ \\
\hline 11 & Termination & Closure \\
\hline
\end{tabular}


reflection sessions. These sessions were very important in increasing the therapeutic effects that the previous session had produced. Participants were expected to take meaning and wisdom from their experiences during the therapy process, which would encourage them to continue practicing tawba and istighfar when the intervention ended.

\section{Results}

A paired sample t-test (Gravetter \& Wallnau, 2013) was used to test the effect of tawba and istighfar intervention in reducing PTSD symptoms. The results show a significant effect of the intervention on the PCL post-test, at $\mathrm{t}(13)=7.42$, $\mathrm{p}<.05, \mathrm{r}=.89$. One week after the intervention, participants showed lower PCL scores ( $M=0.42$, $\mathrm{SD}=0.30)$ than before the intervention $(\mathrm{M}=1.35$, $\mathrm{SD}=0.65$ ). Three weeks after the post-test (followup) there was significant effect of the intervention on the PCL scores ( $\mathrm{M}=0.178, \mathrm{t}=6.95)$. To interpret these results, we referred to Cohen (1998) who established three classifications of effect size: small effect $(\mathrm{r}=.10)$, medium effect $(\mathrm{r}=.30)$ and large effect $(r \geq .50)$. In this case, the effect size was estimated to be large, with $80.9 \%$ (post-test) and $78.80 \%$ (follow-up) of the variance in PTSD symptoms explained by the intervention. A summary of the results is shown in Table 2.

\section{Discussion}

The purpose of the study was to investigate the effectiveness of a type of spiritual intervention based on Islamic teachings, specifically tawba and istighfar, in reducing traumatic symptoms among Muslim college students who had lost a friend in a traffic accident, as well as preventing these symptoms from developing into PTSD. As expected, the students' post-test scores were significantly lower than the pre-test ones and remained at the same level in the follow up, indicating that the intervention was effective. The participants felt its effects at all stages of the process. In the early stage, they seemed to have difficulty in expressing their feelings (e.g., most of them cried), but after a while they were able to express their negative feelings and thoughts, so the pressure they had previously felt was reduced. In the next stage, the participants experienced less anxiety as they tried to return their negative feelings and thoughts to God. Subsequently, they were able to find the meaning of the upsetting event and felt less guilty after sending prayers to their deceased friend. Praying can be considered as a method to alleviate the guilt that comes from trauma. Our findings provide explanations for the benefits of the practices of Islamic teachings for the Muslim community in Indonesia.

The results of the research confirm that tawba and istighfar intervention provides an effective treatment for preventing, a replication of recent findings regarding the effectiveness of tawba and istighfar therapy in improving mental health and subjective well-being (Uyun et al., 2019; Uyun \& Kurniawan, 2018). Our results also reflect those of Pearce, Haynes, Rivera, and Koenig's study (2018), which demonstrated that Spiritually Integrated Cognitive Processing Therapy (SICPT) was effective in reducing PTSD. The positive effects of spiritual-based interventions using different religious approaches, such as Mahayana Buddhist intervention and Christian mindfulness intervention, have been demonstrated in many studies (Trammel, 2017; Wu et al., 2019). Moreover, a correlational study 
Table 2

Results of t-test, Effect Size and Descriptive Statistics for Post-traumatic Symptoms Following Tawba and Istighfar Intervention

\begin{tabular}{|c|c|c|c|c|c|c|}
\hline No & Symptoms & Pre-test & Post-test & $t(d f)$, sig & $\begin{array}{l}\text { Effect size (\% } \\
\text { total variance } \\
\text { explained) }\end{array}$ & $\begin{array}{c}\text { Effect Size } \\
\text { Classification }\end{array}$ \\
\hline 1 & $\begin{array}{l}\text { Is "superalert", watchful or } \\
\text { on guard. }\end{array}$ & $\begin{array}{l}\mathrm{M}=2.28 \\
\mathrm{SD}=0.82\end{array}$ & $\begin{array}{l}\mathrm{M}=0.78 \\
\mathrm{SD}=0.57\end{array}$ & $\begin{array}{c}\mathrm{t}(13)=8.629 \\
\text { sig }<.05\end{array}$ & $r=.922(85.13 \%)$ & Large \\
\hline 2 & $\begin{array}{l}\text { Repeated, disturbing } \\
\text { memories, thoughts, or } \\
\text { images of a stressful } \\
\text { experience from the past. }\end{array}$ & $\begin{array}{l}\mathrm{M}=1.92 \\
\mathrm{SD}=1.07\end{array}$ & $\begin{array}{l}\mathrm{M}=0.71 \\
\mathrm{SD}=0.46\end{array}$ & $\begin{array}{c}t(13)=5.090 \\
\text { sig }<.05\end{array}$ & $r=.816(66.58 \%)$ & Large \\
\hline 3 & $\begin{array}{l}\text { Has trouble falling or } \\
\text { staying asleep. }\end{array}$ & $\begin{array}{l}M=1.42 \\
\mathrm{SD}=1.15\end{array}$ & $\begin{array}{l}M=0.28 \\
S D=0.46\end{array}$ & $\begin{array}{l}t(13)=4.505 \\
\quad \text { sig }<0.05\end{array}$ & $\mathrm{r}=.780(60.95 \%)$ & Large \\
\hline 4 & $\begin{array}{l}\text { Feels emotionally numb or } \\
\text { unable to have loving } \\
\text { feelings for those close to } \\
\text { you. }\end{array}$ & $\begin{array}{l}\mathrm{M}=1.50 \\
\mathrm{SD}=1.01\end{array}$ & $\begin{array}{l}\mathrm{M}=0.28 \\
\mathrm{SD}=0.46\end{array}$ & $\begin{array}{c}t(13)=4.050 \\
\text { sig }<.05\end{array}$ & $\mathrm{r}=.746(55.78 \%)$ & Large \\
\hline 5 & $\begin{array}{l}\text { Feels irritable or has angry } \\
\text { outbursts. }\end{array}$ & $\begin{array}{l}\mathrm{M}=0.85 \\
\mathrm{SD}=0.77\end{array}$ & $\begin{array}{l}M=0.21 \\
S D=0.42\end{array}$ & $\begin{array}{c}t(13)=3.798 \\
\text { sig }<.05\end{array}$ & $\mathrm{r}=.725(52.59 \%)$ & Large \\
\hline 6 & Difficulty in concentrating. & $\begin{array}{l}\mathrm{M}=1.57 \\
\mathrm{SD}=1.28\end{array}$ & $\begin{array}{l}\mathrm{M}=0.50 \\
\mathrm{SD}=0.51\end{array}$ & $\begin{array}{c}t(13)=3.741 \\
\text { sig }<.05\end{array}$ & $\mathrm{r}=.720(51.84 \%)$ & Large \\
\hline 7 & $\begin{array}{l}\text { Has physical reactions (e.g., } \\
\text { pounding heart, trouble } \\
\text { breathing, sweating) when } \\
\text { is reminded of the stressful } \\
\text { experience from the past. }\end{array}$ & $\begin{array}{l}M=1.57 \\
S D=1.28\end{array}$ & $\begin{array}{l}M=0.50 \\
S D=0.65\end{array}$ & $\begin{array}{c}t(13)=3.741 \\
\text { sig }<.05\end{array}$ & $\mathrm{r}=.720(51.84 \%)$ & Large \\
\hline 8 & $\begin{array}{l}\text { Suddenly acts or feels as if } \\
\text { the stressful } \\
\text { experience from the past } \\
\text { were happening again } \\
\text { (as if reliving it). }\end{array}$ & $\begin{array}{l}\mathrm{M}=1.42 \\
\mathrm{SD}=1.08\end{array}$ & $\begin{array}{l}M=0.35 \\
S D=0.49\end{array}$ & $\begin{array}{c}t(13)=3.741 \\
\text { sig }<.05\end{array}$ & $\mathrm{r}=.720(51.84 \%)$ & Large \\
\hline 9 & $\begin{array}{l}\text { Avoids thinking or talking } \\
\text { about the stressful } \\
\text { experience or avoids } \\
\text { having feelings related to it. }\end{array}$ & $\begin{array}{l}M=1.61 \\
S D=1.38\end{array}$ & $\begin{array}{l}M=0.38 \\
S D=0.65\end{array}$ & $\begin{array}{c}t(12)=2.889 \\
\quad \text { sig }<.05\end{array}$ & $\mathrm{r}=.625(39.09 \%)$ & Large \\
\hline 10 & $\begin{array}{l}\text { Loss of interest in activities } \\
\text { that used to be enjoyable. }\end{array}$ & $\begin{array}{l}M=1.07 \\
S D=0.99\end{array}$ & $\begin{array}{l}M=0.50 \\
S D=0.75\end{array}$ & $\begin{array}{c}t(13)=2.828 \\
\quad \text { sig }<.05\end{array}$ & $r=.617(38.08 \%)$ & Large \\
\hline 11 & $\begin{array}{l}\text { Avoids activities or } \\
\text { situations because they are } \\
\text { a reminder of the stressful } \\
\text { experience. }\end{array}$ & $\begin{array}{l}\mathrm{M}=1.35 \\
\mathrm{SD}=1.27\end{array}$ & $\begin{array}{l}M=0.42 \\
S D=0.64\end{array}$ & $\begin{array}{c}t(13)=2.738 \\
\text { sig }<.05\end{array}$ & $r=.604(36.57 \%)$ & Large \\
\hline 12 & $\begin{array}{l}\text { Feels very upset when } \\
\text { reminded of the stressful } \\
\text { experience. }\end{array}$ & $\begin{array}{l}\mathrm{M}=0.92 \\
\mathrm{SD}=1.14\end{array}$ & $\begin{array}{l}M=0.28 \\
S D=0.46\end{array}$ & $\begin{array}{c}t(13)=2.386 \\
\quad \text { sig }<.05\end{array}$ & $\mathrm{r}=.551(30.45 \%)$ & Large \\
\hline 13 & $\begin{array}{l}\text { Feels distant or cut off from } \\
\text { other people. }\end{array}$ & $\begin{array}{l}\mathrm{M}=1.07 \\
\mathrm{SD}=1.14\end{array}$ & $\begin{array}{l}M=0.35 \\
S D=0.63\end{array}$ & $\begin{array}{c}t(13)=2.347 \\
\quad \text { sig }<.05\end{array}$ & $r=.545(29.76 \%)$ & Large \\
\hline 14 & $\begin{array}{l}\text { Has trouble remembering } \\
\text { important parts of the } \\
\text { stressful experience. }\end{array}$ & $\begin{array}{l}\mathrm{M}=1.00 \\
\mathrm{SD}=1.17\end{array}$ & $\begin{array}{l}M=0.42 \\
S D=0.64\end{array}$ & $\begin{array}{c}t(13)= \\
2.104 \text { sig<.05 }\end{array}$ & $r=.504(25.40 \%)$ & Large \\
\hline 15 & $\begin{array}{l}\text { Feels as if the future will } \\
\text { somehow be cut short. }\end{array}$ & $\begin{array}{l}\mathrm{M}=0.92 \\
\mathrm{SD}=0.99\end{array}$ & $\begin{array}{l}M=0.42 \\
S D=0.51\end{array}$ & $\begin{array}{c}t(13)=1.836 \\
\quad \text { sig }<.05\end{array}$ & $\mathrm{r}=.453(20.59 \%)$ & Medium \\
\hline 16 & $\begin{array}{l}\text { Repeated, disturbing } \\
\text { dreams of the stressful } \\
\text { experience. }\end{array}$ & $\begin{array}{l}M=0.57 \\
S D=1.01\end{array}$ & $\begin{array}{l}\mathrm{M}=0.07 \\
\mathrm{SD}=0.26\end{array}$ & $\begin{array}{l}t(13)=1.713 \\
\text { sig }>.05\end{array}$ & $\mathrm{r}=.429(18.41 \%)$ & Medium \\
\hline
\end{tabular}


showed a link between religiosity and the components of subjective well-being, suggesting that religious individuals tend to be more satisfied with their lives than those who are less religious (Gull \& Dawood, 2013). Koenig's review of religiosity/spirituality and mental health research concluded that religious/spiritual beliefs and practices are generally used in medical and psychiatric patients to deal with diseases and stressful life changes. People with high religiosity/spirituality have better mental health and adapt more quickly to health problems compared to those who lack them (Koenig, 2012).

In this study, the participants were assisted in healing their guilty feelings by seeking forgiveness from God, reciting istighfar, and praying for their deceased friend. They were guided to realize that at this point all their friend needed was prayers. Returning bereavement to God is a way of receiving His forgiveness, which allows an individual to achieve a sense of gratitude. As stated in the Quran: "He said, 'O my people, why are you impatient for evil instead of good? Why do you not seek forgiveness of Allah that you may receive mercy? " (Qur'an 27:46). In the reflection sessions the participants were able to attach a meaning to the traumatic experience and reported feeling a stronger sense of belief in Allah. With this belief, they began to have a more positive outlook on loss; rather than something terrifying, they saw it as a lesson from Allah that should be accepted with grace. These results are consistent with Magezi and Manda's findings (2016), that spirituality can act as a coping resource for people in traumatic situations. The results also align with verses from the Quran which state that Allah promises "strength", "good provision", and "favour" to those who seek repentance:
"And 0 my people, ask forgiveness of your Lord and then repent to Him. He will send [rain from] the sky upon you in showers and increase you in strength [added] to your strength. And do not turn away, [being] criminals." (QS. Hūd [11]:52).

"And [saying], "Seek forgiveness of your Lord and repent to Him, [and] He will let you enjoy a good provision for a specified term and give every doer of favor his favor. But if you turn away, then indeed, I fear for you the punishment of a Great Day." (QS. Hūd [11]:3).

\section{Conclusion}

In conclusion, repentance and istighfar therapy alleviated post-traumatic symptoms and prevented the development of Post-traumatic Stress Disorder (PTSD). The strength of this study is the generalizability of the findings, which are not limited to the participants who were experiencing traumatic symptoms. The results indicate that the more participants complied with the treatment process, the higher the treatment efficacy. Based on this explanation, it is assumed that tawba and istighfar therapy is effective in treating other types of psychological disorders, as long as participants are committed to follow each step of the therapy process. In addition, this type of intervention produces sustainable effects because tawba and istighfar are daily obligations of Muslims, who have internalized the values and principles of these rituals in their everyday lives. Therefore, it makes the intervention more convenient for them to practice. Further research is needed to evaluate the effectiveness of the intervention on different populations. The results of the study highlight the importance of integrating a spiritual/religious approach into psychotherapy in order to achieve optimal treatment effectiveness. 
Acknowledgments

This work was supported by Departemen Penelitian dan Pengabdian pada Masyarakat Universitas Islam Indonesia. We also thank
Ustadz Hamdani Bakran adz-Dzakiey for supervising the therapy.

Declaration of Interest

We have no conflicts of interest to disclose.[]

\section{References}

Adz-Dzakiey, H. B. (2007). Psikologi kenabian: Menghidupkan potensi dan kepribadian kenabian dalam diri. Pustaka Al Furqan.

American Psychiatric Association. (2013). Diagnostic and statistical manual of mental disorders (5th ed.). American Psychiatric Association. https://doi.org/10.1176/appi.books.9780890425596

Bisson, J. I., Cosgrove, S., Lewis, C., \& Roberts, N. P. (2015). Post-traumatic stress disorder. BMJ, 351(6161), h6161. https://doi.org/10.1136/bmj.h6161

Casement, M. D., \& Swanson, L. M. (2012). A meta-analysis of imagery rehearsal for post-trauma nightmares: Effects on nightmare frequency, sleep quality, and posttraumatic stress. Clinical Psychology Review, 32(6), 566-574. https://doi.org/10.1016/j.cpr.2012.06.002

Charuvastra, A., \& Cloitre, M. (2008). Social bonds and posttraumatic stress disorder. Annual Review of Psychology, 59(1), 301-328. https://doi.org/10.1146/annurev.psych.58.110405.085650

Cohen, J. (1998). Statistical power analysis for the behavioral sciences. Routledge. https://doi.org/10.4324/9780203771587

Creamer, M., Burgess, P., \& McFarlane, A. C. (2001). Post-traumatic stress disorder: Findings from the Australian national survey of mental health and well-being. Psychological Medicine, 31(7), 1237-1247. https://doi.org/10.1017/S0033291701004287

Davidson, J. R. T. (2000). Trauma: The impact of post-traumatic stress disorder. Journal of Psychopharmacology, 14(2_suppl1), S5-S12. https://doi.org/10.1177/02698811000142S102

Field, A., \& Hole, G. J. (2008). How to design and report experiments. Sage Publication Inc.

al-Ghazali. (2013). Ihya Ulumiddin: Menghidupkan kembali ilmu-ilmu agama. Pintu taubat. Republika.

Gisela, V., \& Kurniawan, I. N. (2014). Studi pendahuluan religiusitas Islam dan kebermaknaan hidup pasangan suami istri. Universitas Islam Indonesia, Yogyakarta.

Gravetter, F. J., \& Wallnau, L. B. (2013). Statistics for behavioral sciences (9th ed.). Wadsworth, Cengage Learning.

Gros, D. F., Flanagan, J. C., Korte, K. J., Mills, A. C., Brady, K. T., \& Back, S. E. (2016). Relations among social support, PTSD symptoms, and substance use in veterans. Psychology of Addictive Behaviors, 30(7), 764-770. https://doi.org/10.1037/adb0000205

Gull, F., \& Dawood, S. (2013). Religiosity and subjective well-being amongst institutionalized elderly in Pakistan. Health Promotion Perspective, 3(1), 124-128. https://doi.org/10.5681/hpp.2013.014

Harits, C. N., \& Kurniawan, I. N. (2016). Religiusitas Islam dan kepuasan pernikahan pasangan suami istri. Universitas Islam Indonesia, Yogyakarta. 
Harris, A. H. S., Thoresen, C. E., Mccullough, M. E., \& Larson, D. B. (1999). Spiritually and religiously oriented health interventions. Journal of Health Psychology, 4(3), 413-433. https://doi.org/10.1177/135910539900400309

Holliday, R., Smith, J., North, C., \& Surís, A. (2015). Developing the PTSD checklist-I/F for the DSM-IV (PCL-I/F): Assessing PTSD symptom frequency and intensity in a pilot study of male veterans with combat-related PTSD. Behavioral Sciences, 5(1), 59-69. https://doi.org/10.3390/bs5010059

al-Jauziyyah, I. Q. (2014). Ensiklopedia taubat. Dari dosa menuju syurga (A. Dzulfikar (trans.)). Keira Publishing.

Kar, N. (2011). Cognitive behavioral therapy for the treatment of post-traumatic stress disorder: A review. Neuropsychiatric Disease and Treatment, 7, 167-181. https://doi.org/10.2147/NDT.S10389

Kessler, R. C., Aguilar-Gaxiola, S., Alonso, J., Benjet, C., Bromet, E. J., Cardoso, G., Degenhardt, L., de Girolamo, G., Dinolova, R. V., Ferry, F., Florescu, S., Gureje, O., Haro, J. M., Huang, Y., Karam, E. G., Kawakami, N., Lee, S., Lepine, J.-P., Levinson, D., ... Koenen, K. C. (2017). Trauma and PTSD in the WHO world mental health surveys. European Journal of Psychotraumatology, 8(sup5), 1353383. https://doi.org/10.1080/20008198.2017.1353383

Keyes, K. M., Pratt, C., Galea, S., McLaughlin, K. A., Koenen, K. C., \& Shear, M. K. (2014). The burden of loss: Unexpected death of a loved one and psychiatric disorders across the life course in a national study. American Journal of Psychiatry, 171(8), 864-871. https://doi.org/10.1176/appi.ajp.2014.13081132

Khairiyah, U., Prabandari, Y. S., \& Uyun, Q. (2015). Terapi zikir terhadap peningkatan resiliensi penderita Low Back Pain (LBP). Jurnal Ilmiah Psikologi Terapan, 3(2), 336-346. https://doi.org/10.22219/jipt.v3i2.3537

Koenig, H. G. (2012). Religion, spirituality, and health: The research and clinical implications. ISRN Psychiatry, 1-33. https://doi.org/10.5402/2012/278730

Lang, A. J., Wilkins, K., Roy-Byrne, P. P., Golinelli, D., Chavira, D., Sherbourne, C., Rose, R. D., Bystritsky, A., Sullivan, G., Craske, M. G., \& Stein, M. B. (2012). Abbreviated PTSD Checklist (PCL) as a guide to clinical response. General Hospital Psychiatry, 34(4), 332-338. https://doi.org/10.1016/j.genhosppsych.2012.02.003

Magezi, V., \& Manda, C. (2016). The use of spiritual resources to cope with trauma in daily existence. In Die Skriflig/In Luce Verbi, 50(1), 2145-2154. https://doi.org/10.4102/ids.v50i1.2145

al-Naishabūry, M. bin al-Ḥajjāj A. al-Ḥasan al-Q. (n.d.). Șaḥịh Muslim. Dār al-Fikr.

Oltmanns, T. F., \& Emery, R. E. (2003). Abnormal psychology. Prentice Hall.

Pearce, M., Haynes, K., Rivera, N. R., \& Koenig, H. G. (2018). Spiritually integrated cognitive processing therapy: A new treatment for post-traumatic stress disorder that targets moral injury. Global Advances in Health and Medicine, 7, 216495611875993. https://doi.org/10.1177/2164956118759939

Perrin, M., Vandeleur, C. L., Castelao, E., Rothen, S., Glaus, J., Vollenweider, P., \& Preisig, M. (2014). Determinants of the development of post-traumatic stress disorder, in the general population. Social Psychiatry and Psychiatric Epidemiology, 49(3), 447-457. https://doi.org/10.1007/s00127-013-0762-3

Philips, A. A. B. (1990). Salvation through repentance (an Islamic view). Riyadh: Internationl Islamic Publishing House. 
Read, J. P., Griffin, M. J., Wardell, J. D., \& Ouimette, P. (2014). Coping, PTSD symptoms, and alcohol involvement in trauma-exposed college students in the first three years of college. Psychology of Addictive Behaviors, 28(4),1052-1064. https://doi.org/10.1037/a0038348

Sareen, J. (2014). Posttraumatic stress disorder in adults: Impact, comorbidity, risk factors, and treatment. The Canadian Journal of Psychiatry, 59(9), 460-467. https://doi.org/10.1177/070674371405900902

Sijbrandij, M., Olff, M., Reitsma, J. B., Carlier, I. V. E., de Vries, M. H., \& Gersons, B. P. R. (2007). Treatment of acute posttraumatic stress disorder with brief cognitive behavioral therapy: A randomized controlled trial. American Journal of Psychiatry, 164(1), 82-90. https://doi.org/10.1176/ajp.2007.164.1.82

Skelton, K., Ressler, K. J., Norrholm, S. D., Jovanovic, T., \& Bradley-Davino, B. (2012). PTSD and gene variants: New pathways and new thinking. Neuropharmacology, 62(2), 628-637. https://doi.org/10.1016/j.neuropharm.2011.02.013

Trammel, R. C. (2017). Tracing the roots of mindfulness: Transcendence in Buddhism and Christianity. Journal of Religion \& Spirituality in Social Work: Social Thought, 36(3), 367-383. https://doi.org/10.1080/15426432.2017.1295822

al-Utsaimin, M. B. S. (2015). Syarah riyadhus shalihin. Darus Sunnah.

Uyun, Q., \& Kurniawan, I. N. (2018). Taubat (repentance) and istighfar (Seek forgiveness from Allah): Therapy to improve subjective well-being of Master Students: A preliminary study. Advanced Science Letters, 24(7), 5422-5425. https://doi.org/10.1166/asl.2018.11748

Uyun, Q., Kurniawan, I. N., \& Jaufalaily, N. (2019). Repentance and seeking forgiveness: The effects of spiritual therapy based on Islamic tenets to improve mental health. Mental Health, Religion \& Culture, 22(2), 185-194. https://doi.org/10.1080/13674676.2018.1514593

Uyun, Q., \& Witruk, E. (2017). The effectiveness of sabr (patience) and salat (prayer) in reducing psychopathological symptoms after the 2010 Merapi eruption in the region of Yogyakarta, Indonesia. In Trends and Issues in Interdisciplinary Behavior and Social Science. CRC Press, Taylor \& Francis Group.

Wainrib, B. R. (2006). Healing crisis and trauma with min, body, and spirit. Springer Publishing Company, Inc.

Wu, B. W. Y., Gao, J., \& Leung, H. K. (2019). A randomized controlled trial of Awareness Training Program (ATP), a group-based Mahayana Buddhist intervention. Mindfulness, 10, 1280-1293. https://doi.org/10.1007/s12671-0182-1 
This page has been intentionally left blank. 